\title{
Interpersonal Relationships among College Students: an Assessment
}

\section{J. Parameswari ${ }^{1}$}

\section{ABSTRACT:}

Developing and maintaining interpersonal relationship is important for success in life. Interpersonal relationship serves as a base for social support that plays a crucial role particularly in emotionally charged situations. It is also noted that interpersonal relationship enhances overall wellbeing of man. The present study is done to find out how students behave and what kind of behavior they expect from others. For this purpose, FIRO - B questionnaire developed by Schultz (1958) was used with a sample of 200 college students who were selected through stratified random sampling method from two colleges in Salem city. The strata used in this study are gender, discipline and order of birth. The collected data were analyzed using t-test that revealed significant gender difference in expressed inclusion and wanted control dimensions of interpersonal relationship. Further, arts discipline students significantly differed from science discipline students in wanted control. There was a significant difference in expressed inclusion and wanted affection based on order of birth of the students.

Keywords: FIRO -B, interpersonal relationship, college students, adolescents.

\section{BACKGROUND:}

Interpersonal relationship is the relationship between two or more individuals. Human beings are gregarious in nature. Though being social is innate nature of mankind, life experiences help in shaping the relationship with others. Developing and maintaining interpersonal relationship is important for success in life. Interpersonal relationship serves as a base for social support that plays a crucial role particularly in emotionally charged situations. It is also noted that interpersonal relationship enhances overall wellbeing of man. Goswami(2012) studied the positive and negative quality relationship and wellbeing of children and reported that positive relationship with family, neighbourhood and friends increases wellbeing of children, whereas negative relationships tend to decrease their wellbeing. Among students, relationship determines their achievement and also relationship encourages performance (Aspelin, 2012). Interpersonal relationship predicts emotional distress. Students with high level of interpersonal relationship showed low level of emotional distress (Kenny, Dooley \& Fitzgerald, 2012)

\footnotetext{
${ }^{1}$ Assistant Professor, Department of Psychology, Periyar University, Salem, Tamilnadu, India
} 


\section{AIM:}

To assess college students' behavior towards others and their expectation from others.

\section{HYPOTHESES:}

1. There is a significant gender difference in interpersonal relationship

2. Arts and science students differ in their interpersonal relationship

3. Students significantly differ in their interpersonal relationship based on their order of birth

\section{RESEARCH METHOD}

\section{Sample}

A sample of 200 college students were selected through stratified random sampling method from two colleges in Salem city. The strata used in this study are gender, discipline and order of birth.

\section{Tool used:}

FIRO - B questionnaire developed by Schultz (1958) was used to measure interpersonal relationship of adolescents. This questionnaire consists of 54 questions to be answered on a 6 point scale. This scale has good reliability with inter-rater reliability ranging form 0.85 to 0.96 and test-retest reliability ranging form0.71 to 0.85 .

\section{RESULTS AND DISCUSSION}

Table 1: Gender difference in interpersonal relationship

\begin{tabular}{|c|c|c|c|c|}
\hline $\begin{array}{l}\text { Dimensions of } \\
\text { interpersonal relationship }\end{array}$ & $\begin{array}{l}\text { Gender } \\
(\mathrm{N}=100 \text { each })\end{array}$ & Mean & $\mathrm{SD}$ & t- Value \\
\hline \multirow[t]{2}{*}{ Expressed inclusion } & Male & 3.83 & 1.16 & \multirow[t]{2}{*}{$3.31 *$} \\
\hline & Female & 4.54 & 1.80 & \\
\hline \multirow[t]{2}{*}{ Expressed control } & Male & 3.75 & 1.47 & \multirow[t]{2}{*}{0.65} \\
\hline & Female & 3.90 & 1.75 & \\
\hline \multirow[t]{2}{*}{ Expressed affection } & Male & 3.72 & 1.32 & \multirow[t]{2}{*}{0.29} \\
\hline & Female & 3.66 & 1.92 & \\
\hline \multirow[t]{2}{*}{ Wanted inclusion } & Male & 2.73 & 1.33 & \multirow[t]{2}{*}{1.59} \\
\hline & Female & 2.37 & 1.84 & \\
\hline \multirow{2}{*}{ Wanted control } & Male & 5.86 & 1.92 & \multirow[t]{2}{*}{$5.83 *$} \\
\hline & Female & 4.17 & 2.17 & \\
\hline \multirow{2}{*}{ Wanted affection } & Male & 3.17 & 1.46 & \multirow[t]{2}{*}{1.79} \\
\hline & Female & 2.78 & 1.62 & \\
\hline
\end{tabular}

\footnotetext{
* Significant at 0.05 level
} 
From the above table it is seen that there is a significant gender difference in two sub-dimensions of interpersonal relationship, namely expressed inclusion and wanted control.Bakken and Romig(1992) in their study reported gender difference in expressed control and wanted affection. They reported that males showed high preference for expressed control and low preference for affection, whereas females showed preference for affection and low preference for expressed control. In the present study, girls show high level of expressed inclusion compared to boys. By nature girls prefer being in group. They while-away their time discussing or gossiping with their group. They feel more comfortable in a group than alone. They show their real self in the group than when they are alone. This may be the reason for their high score in expressed inclusion. Boys show high preference for wanted control than girls. It is rare for boys to be emotionally close in their relationship. They have different group of friends to meet their different needs. For example, boys may have a friend to accompany them for shopping, another friend to guide in taking important decisions. Boys may not know to effectively use the autonomy given to them. They need someone to guide them in the right direction. These may be the reasons for their score in need for wanted control.

Table 2: Difference in interpersonal relationship based on discipline

\begin{tabular}{|c|c|c|c|c|}
\hline $\begin{array}{l}\text { Dimensions of } \\
\text { interpersonal relationship }\end{array}$ & $\begin{array}{l}\text { Discipline } \\
(\text { Science }=106 \text { Arts=94) }\end{array}$ & Mean & SD & t- Value \\
\hline \multirow[t]{2}{*}{ Expressed inclusion } & Science & 4.22 & 1.73 & \multirow[t]{2}{*}{0.31} \\
\hline & Arts & 4.15 & 1.33 & \\
\hline \multirow[t]{2}{*}{ Expressed control } & Science & 3.87 & 1.76 & \multirow[t]{2}{*}{0.40} \\
\hline & Arts & 3.78 & 1.45 & \\
\hline \multirow[t]{2}{*}{ Expressed affection } & Science & 3.78 & 1.72 & \multirow[t]{2}{*}{0.85} \\
\hline & Arts & 3.59 & 1.54 & \\
\hline \multirow[t]{2}{*}{ Wanted inclusion } & Science & 2.41 & 1.58 & \multirow[t]{2}{*}{1.35} \\
\hline & Arts & 2.71 & 1.62 & \\
\hline \multirow[t]{2}{*}{ Wanted control } & Science & 4.64 & 2.31 & \multirow[t]{2}{*}{$2.59 *$} \\
\hline & Arts & 5.44 & 2.03 & \\
\hline \multirow[t]{2}{*}{ Wanted affection } & Science & 3.01 & 1.58 & \multirow[t]{2}{*}{1.38} \\
\hline & Arts & 2.94 & 1.52 & \\
\hline
\end{tabular}

*Significant at 0.05 level

The above table makes it clear that there is a significant difference in wanted control between students of art and science discipline. Students from arts discipline have high need for wanted control than the students from science discipline. From the secondary school onwards students of science stream have a defined goal and also have the motive to reach the goal. They work on their own and know how to attain their goal. Even if they have no concrete goal, their degree will fetch them a job. But this is not so with the arts discipline students. The students of arts stream tend to be lethargic and have no concrete plan for their future. This is because they are not sure 
of the scope of their subject. Most of the arts students lack the skill to sell their talents. Therefore, they are in need of guidance in setting goals and taking decisions about their career especially.

Table 3: Difference in interpersonal relationship based on order of birth

\begin{tabular}{|c|c|c|c|c|}
\hline $\begin{array}{l}\text { Dimensions of } \\
\text { interpersonal relationship }\end{array}$ & $\begin{array}{l}\text { Order of birth } \\
\text { (First born=80 } \\
\text { Later } \\
\text { born=92) }\end{array}$ & Mean & SD & t- Value \\
\hline \multirow[t]{2}{*}{ Expressed inclusion } & First born & 4.55 & 1.53 & \multirow[t]{2}{*}{$3.69^{*}$} \\
\hline & Later born & 3.71 & 1.45 & \\
\hline \multirow[t]{2}{*}{ Expressed control } & First born & 3.92 & 1.51 & \multirow[t]{2}{*}{0.79} \\
\hline & Later born & 3.74 & 1.59 & \\
\hline \multirow[t]{2}{*}{ Expressed affection } & First born & 3.71 & 1.73 & \multirow[t]{2}{*}{0.28} \\
\hline & Later born & 3.64 & 1.52 & \\
\hline \multirow[t]{2}{*}{ Wanted inclusion } & First born & 2.61 & 1.72 & \multirow[t]{2}{*}{0.64} \\
\hline & Later born & 2.46 & 1.49 & \\
\hline \multirow[t]{2}{*}{ Wanted control } & First born & 5.09 & 2.46 & \multirow[t]{2}{*}{0.35} \\
\hline & Later born & 5.21 & 1.99 & \\
\hline \multirow[t]{2}{*}{ Wanted affection } & First born & 3.34 & 1.50 & \multirow[t]{2}{*}{$2.74 *$} \\
\hline & Later born & 2.71 & 1.52 & \\
\hline
\end{tabular}

*Significant at 0.05 level

Table 3 shows the difference in interpersonal relationship based on order of birth. It is clear from the table that there is a significant difference in expressed inclusion and wanted affection between first born and later born adolescents. First born children show high need for expressed inclusion than later born children. It is natural for elder children to show concern, attention and care for younger ones at home. This behavior tend to extend to social settings also.

First born children also show a high need for wanted affection compared to later born children. Parents tend to show more attention and care to younger child than the elder child, believing that the elder child can take care of self. At this stage the elder child may feel left out and their need for affection may increase.

\section{REFERENCES}

Kenny, R., Dooley, B., and Fitzgerald, A. (2013).Interpersonal relationships and emotional distress in adolescence.Journal of Adolescence. 36(2), 351-360.

Goswami, H. (2012). Social relationships and children's subjective wellbeing.Social Indicators Research. 107(3), 575-588. 
Aspelin, J. (2012). How do relationships influence student achievement?Understanding student performance from a general, social, psychological standpoint.International Studies in Sociology of Education. 22(1), 41-56.

Schutz, W.C. (1958). FIRO: A three dimensional theory of interpersonal behavior. New York: Holt, and Winston.

Bakken, L., and Romig, C. (1992). Interpersonal needs in middle adolescents: companionship, leadership and intimacy. Journal of Adolescence. 15(3), 301-316. 